\title{
DEVELOPMENT OF RECIPES AND ESTIMATION OF THE NUTRIENT COMPOSITION OF CARDIO-PROTECTIVE FRESH-MIXES
}

\author{
Nadya Dzyuba \\ Department of restaurant and health food technology \\ Odessa National Academy of Food Technologies \\ 112 Kanatna str., Odessa, Ukraine, 65039 \\ adya282@rambler.ru,dzyubanadya282@gmail.ru \\ Liubov Telezhenko \\ Department of restaurant and health food technology \\ Odessa National Academy of Food Technologies \\ 112 Kanatna str., Odessa, Ukraine, 65039 \\ telegenko@ukr.net \\ Maryana Kashkano \\ Department of restaurant and health food technology \\ Odessa National Academy of Food Technologies \\ 112 Kanatna str., Odesa, Ukraine, 65039 \\ marykash@ukr.net

\section{Svitlana Vikul} \\ Department of food chemistry \\ Odessa National Academy of Food Technologies \\ 112 Kanatna str., Odesa, Ukraine, 65039 \\ vizaj_vik@ukr.net

\section{Olesia Priss}

Department of Technology of Processing and Storage of Agricultural Products Tavria State Agrotechnological University,

18 B. Khmelnitskogo ave., Melitopol, Ukraine, 72310 olesyapriss@gmail.com

\section{Valentina Zhukova}

Department of Technology of Processing and Storage of Agricultural Products Tavria State Agrotechnological University

18 B. Khmelnitskogo ave., Melitopol, Ukraine, 72310

zhuzhuvf@gmail.com

\section{Kiurcheva Lyidmila}

Department of Technology of Processing and Storage of Agricultural Products

Tavria State Agrotechnological University

18 B. Khmelnitskogo ave., Melitopol, Ukraine, 72310

lyidmila2007@ukr.net

\section{Nona Gaprindashvili}

Department of Technology of Processing and Storage of Agricultural Products

Tavria State Agrotechnological University

18 B. Khmelnitskogo ave., Melitopol, Ukraine, 72310

tpzpsg@tsatu.edu.ua 


\section{Abstract}

The aim of the work is the development of recipes of fresh-mixes with the balanced potassium-protein composition and expressed cardio- and protective properties.

For creating recipes of cardio-protective fresh mixes, there was used linear programming in MS Excel redactor. The target function was the balanced P-protein composition.

The potassium content was $148-190 \mathrm{~g}$ for $100 \mathrm{~g}$ of the ready beverage that covers in average $6-8 \%$ of the daily potassium need in patients with cardio-vascular diseases. At the expanse of introducing glutin, beverages contain oxylizin and oxyproline in concentration $0,15 \ldots 0,2 \%$. The energetic value of developed fresh-mixes was 58,8-64,6 kcal.

There was determined biological activity of developed beverages by the index of non-enzymatic oxidation of NAD $\mathrm{H}_{2}$ to NAD. At the development of beverages, there was fixed the effect of synergism at the expanse of introducing the spicy-aromatic raw material - turmeric and the protein one - glutin.

ALST test, based on changing microbiological and sensory indices at storage, demonstrated the optimal storage term 5 days at the temperature $(5 \pm 1)^{\circ} \mathrm{C}$ in a hermetic package.

Fresh-mixes, enriched with potassium and easily assimilated protein were developed for the first time. They can not only satisfy needs in these nutrients but favor production of own protein of the connective tissue, for keeping the healthy condition of the cardiac muscle.

Keywords: immune-stimulating beverage, mathematical modeling, biological activity, complex quality estimation.

\title{
1. Introduction
}

The essential food role is played by beverages, based on natural raw materials that realize diverse functions in the human organism: satisfy needs in liquids, compensate the deficit of vitally important biologically active substances, act as an effective instrument of prophylaxis of spread alimentary disease [1-4].

In last time the great importance was acquired by beverages, based of phyto-components [1-4]. As a protein source, there is used the fish protein concentrate, produced of spines of salmon fishes $[5,6]$, collagen hydrolysate of carp scales (glutin) [7, 8]. The ability of fish protein to stimulate production of own collagen of the organism and also its moisture-keeping properties favor creation of different health food products.

Cardio-vascular diseases (CVD) are the main cause of death throughout the world. According to estimations, in 2012 17,5 million people died because of them that was $31 \%$ of all death cases in the world. Among them 7,4 million people died of the ischemic heart disease and 6,7 as a result of a stroke. More than $75 \%$ of cases of death of CVD take place in countries with low and middle income levels. $82 \%$ of cases of death of 16 million ones of non-infectious diseases before 70 years cover countries with low and middle income levels, and CVD are the cause of $37 \%$ of them [9-14].

Most cardio-vascular diseases can be prevented by taking measures as to risk factors such as tobacco and alcohol consumption, unhealthy food and obesity, absence of physical activity, using strategies that cover the whole population.

People with CVD or high risk of them (increased blood pressure, diabetes, hyperlipidemia or already developed disease), need early detection and help by consulting and taking medicaments, if necessary.

As far as preventive measures and prophylaxis of such problems with population health have the special importance, the problem of the development of food products, especially, beverages, based on compositions of vegetable raw materials with expressed functional properties, remain urgent for food industry.

The aim of the work is the development of recipes of fresh-mixes with the balanced potassium-protein composition and expressed cardio- and protective properties. It allows widen the assortment of this group of beverages for all social groups of the population.

The following questions were set for attaining this aim:

- to develop recipes of fresh-mixes with the optimal content of potassium, protein and antioxidants of the vegetable origin;

- to conduct ASLT analysis for determining storage conditions of ready products. 


\section{Materials and Methods}

The studies were carried out on the base of modern scientific laboratories:

- Department of restaurant and health food technology of Odessa National Academy of Food Technologies, (city Odessa, Ukraine); Ukraine);

- Laboratory of Physical-chemical institute, named after A.V. Bogatsky, (city Odessa,

- Department of Technology of Processing and Storage of Agricultural Products of Tavria State Agrotechnological University (city Melitopol, Ukraine).

The following equipment was used for the studies:

- For producing fresh-mixes, there was used a juicer KENWOOD JE850 (Japan), blender (PHILIPS HR-1633/80, China), refrigerator (RC-0,4 MC, Mari El Republic, Russia), washer and table electric weights (Rotex RSK 10-P, China);

- For determining antioxidant activity, there was used a photometric potential colorimeter CPC-2MP (Russia); Russia);

- For realizing ALST test there was used a refrigerator (RC-0,4 MC, Mari El Republic,

- For the studies of microbiological safety, there were used: an autoclave Systec VX (Ukraine), electric dry-air thermostat CD -200 (Russia), microscope XSM-20 (Ukraine)

For producing fresh-beverages, there were used: fresh-juices: pomegranate, beet, pumpkin, apple and grapefruit, turmeric and glutin.

Mathematical modeling of the compositional content of fresh-mixes was realized using linear programming using MS Excel 2007 redactor [15].

For the complex quality estimation of developed fresh-juices, there was used the multiplicative type of the additive model of complex estimation [16].

Microbiological indices of beverages were determined by the normative document SSTU 4069:2016 and presented in Table 1.

Table 1

Microbiological parameters of the beverage on the juice base

\begin{tabular}{ccc}
\hline Parameters & $\begin{array}{c}\text { Norm } \\
\text { (SSTU 4069:2016) }\end{array}$ & Detection method \\
\hline $\begin{array}{c}\text { Bacteria of colibacillus coliform group (BCG), volume } \mathrm{cm}^{3} \text {, that they are } \\
\text { not allowable in }\end{array}$ & 333 & SSTU SST 30712 \\
$\begin{array}{c}\text { Amount of mesophilic anaerobic and faculatative-anaerobic microorgan- } \\
\text { isms, CFU } / \mathrm{cm} 3 \text {, no more }\end{array}$ & 0 & SST 1044.15 \\
$\begin{array}{c}\text { Pathogenic microorganisms, including Salmonella, volume } \mathrm{cm}^{3} \text {, that they } \\
\text { are not allowable in }\end{array}$ & 25 & SSTU IDF 93A \\
Amount of molds and yeast (sum), CFU $/ \mathrm{cm}^{3}$ & 100 & SST 10444.12 \\
Amount of ferment bacteria, $\mathrm{CFU} / \mathrm{cm}^{3}$ & 0 & SST 10444.11
\end{tabular}

For determining BA, there was used a spectrophotometer CPC-2MP (Russia) with the working wave length $\lambda=335 \mathrm{Nm}$ and time of reagents' interaction $\tau=180 \mathrm{~s}$ [18].

\section{Experimental procedures}

As a criterion of optimality or target function of the mathematical model, there was used the maximal content of potassium, because it just influences the cardiac muscle.

The target function (1) corresponds to the maximal potassium content in the recipe. Limitations (2) and boundary conditions (3) are used for regulating both the recipe content of components and separate nutrients of the raw material. The content of glutin was taken in the limits $1 . .5 \%$ that provides necessary rheological properties of the liquid food system. The content of oxylyzin and oxyproline, which source is glutin, correspondingly, varied within $0,15 \ldots 0,2 \mathrm{~g} / 100 \mathrm{~g}$ that in its turn provides the increased biological value of a product and is enough for forming the human articular 
tissue. The energetic value of fresh-mixes was limited by the boundary value 60 ckal that is explained by getting low-cal beverages.

$$
\begin{gathered}
F=f\left(x_{1}, \ldots x_{i}, \ldots x_{n}\right) \rightarrow \text { const }, \quad i=\overline{1, n}, \\
x_{i} \leq(=, \geq) b_{i}, \quad i=\overline{1, n}, \\
d_{k} \leq x_{k} \leq D_{k}, \quad k=\overline{1, n},
\end{gathered}
$$

where $\mathrm{F}$ - target function of the linear model; $\mathrm{x}_{\mathrm{i}}$ - recipe component of the product, $\%$; $\mathrm{b}_{\mathrm{i}}-\lim$ itations in the content of $\mathrm{i}$-th component in the recipe, $\% ; \mathrm{x}_{\mathrm{k}}-$ content of the nutrient $\mathrm{k}$ in the recipe, $\% ; d_{k}, D_{k}$ - low and upper limitation for the content of the nutrient $x_{k}, \% ; n-$ number of recipe components and nutrients.

The maximal potassium content was chosen as a target function of the mathematical model at developing the recipe of fresh-mixes "Potassium-mix" and Potassium-mix plus" (Fig. 1):

$$
\mathrm{Z}\left(\mathrm{x}_{\mathrm{i}}\right)=\max ,
$$

where $\mathrm{Z}\left(\mathrm{x}_{\mathrm{i}}\right)$ - target function that reflects the potassium mass share in the recipe, $\mathrm{mg} / 100 \mathrm{ml} ; \mathrm{x}_{\mathrm{i}}-$ recipe component, $\%$.

The search for a solution at that was realized by the simplex-method [16].

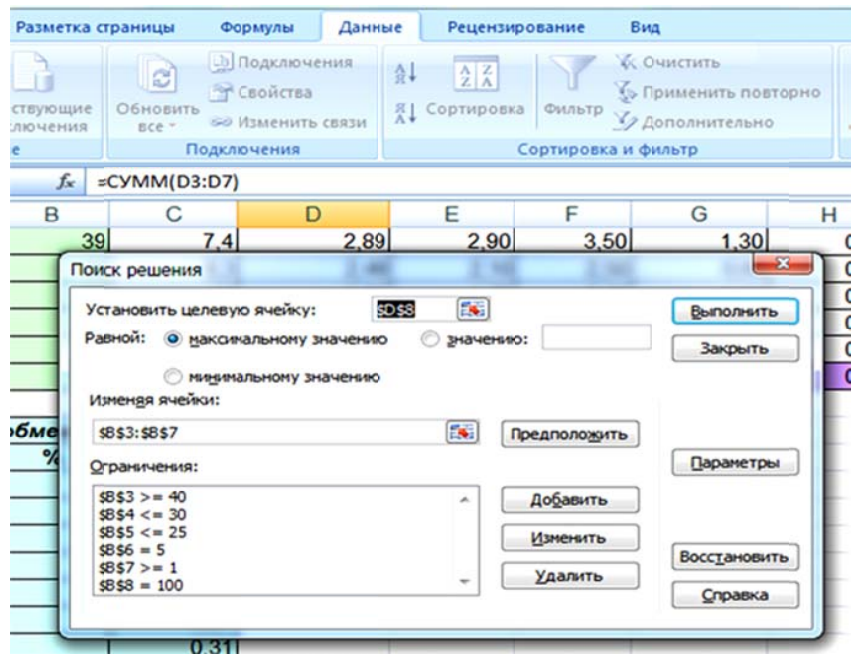

Fig. 1. Procedure of projecting recipe compositions of fresh-mixes using the superstructure "search for solution" of MS Excel (simplex-method)

The problem of searching a generalized quality criterion is considered as a vague nonlinear programming with $\mathrm{n}$ inconsistent criteria, $\mathrm{m}$ variables of equations and $\mathrm{k}$ nonlinear limitations:

$$
\text { Optimize } \mathrm{K}\left[\mathrm{K}_{1}(\mathrm{X}), \mathrm{K}_{2}(\mathrm{X}), \ldots \mathrm{K}_{\mathrm{n}}(\mathrm{X})\right] \text {, }
$$

At

$$
\begin{gathered}
\mathrm{C}_{\mathrm{i}} \equiv \mathrm{G}_{\mathrm{Li}} \leq \mathrm{G}_{\mathrm{i}}(\mathrm{X}) \leq \mathrm{G}_{\mathrm{Ui}}, \quad \mathrm{i}=1,2, \ldots \mathrm{k}, \\
\mathrm{x}_{\mathrm{Li}} \leq \mathrm{x}_{\mathrm{i}} \leq \mathrm{x}_{\mathrm{Ui}}, \quad \mathrm{i}=1,2, \ldots \mathrm{m},
\end{gathered}
$$

where $\mathrm{K}_{1}(\mathrm{x})$ is presented by the vague nonlinear criterion of the product quality; $\mathrm{X}\left(\mathrm{x}_{1}, \mathrm{x}_{2}, \ldots, \mathrm{x}_{\mathrm{m}}\right)$ vector of determined variables of the equation; $\mathrm{G}_{\mathrm{Li}}, \mathrm{G}_{\mathrm{Ui}}$ - low and upper limits, respectively; $\mathrm{x}_{\mathrm{Li}} \leq$ $\leq \mathrm{x}_{\mathrm{i}} \leq \mathrm{x}_{\mathrm{Ui}}$ - low and upper limits for determined variables of management. 
The parameters of $\mathrm{X}_{\mathrm{opt}}$ model equate the compromise solution for effectiveness criteria. The multi-criteria approach is based on the combination of formal and informal procedures of making decision for an alternative solution of the problem. The final solution is determined as a result of crossing all vague criteria and limits, reflected by their membership functions $\mu(X)$ :

$$
\mu_{\mathrm{k}}(X)=\mu_{\mathrm{k} 1}(X) \cap \ldots \mu_{\mathrm{kn}}(X) \bigcap \mu_{\mathrm{Gi}}(X), \quad \mathrm{i}=1,2, \ldots \mathrm{k} ; \quad X \in X_{\mathrm{p}}
$$

Maximal and min minimal limits of criteria are determined:

$$
\begin{gathered}
K_{i}^{\min }=\min _{j} K_{j}\left(X_{j}^{0}\right)=K_{i}\left(X_{i}^{o}\right), \quad i=1 \ldots n, \\
K_{i}^{\max }=\max _{j} K_{j}\left(X_{j}^{0}\right), \quad i=1 \ldots n .
\end{gathered}
$$

The membership function for all vague targets is presented as:

$$
\mu_{\mathrm{Ki}}(\mathrm{X})= \begin{cases}0, & \text { if } \mathrm{K}_{\mathrm{i}}(\mathrm{X})>\mathrm{K}_{\mathrm{i}}^{\max }, \\ \frac{\mathrm{K}_{\mathrm{i}}^{\max }-\mathrm{K}_{\mathrm{i}}}{\mathrm{K}_{\mathrm{i}}^{\max }-\mathrm{K}_{\mathrm{i}}^{\min },} & \text { if } \mathrm{K}_{\mathrm{i}}^{\min }<\mathrm{K}_{\mathrm{i}} \leq \mathrm{K}_{\mathrm{i}}^{\max }, \\ 1, & \text { if } \mathrm{K}_{\mathrm{i}}(\mathrm{X}) \leq \mathrm{K}_{\mathrm{i}}^{\mathrm{min}} .\end{cases}
$$

Vague limitations are formulated as following:

$$
\mathrm{C}_{\mathrm{j}}(\mathrm{X}) \leq \mathrm{C}_{\mathrm{j}}^{\max }+\mathrm{d}_{\mathrm{j}}, \quad \mathrm{j}=1,2, \ldots \mathrm{q}
$$

where $d_{j}$ - real parameter that determines the distance from the permissible shift to the boundary $\mathrm{C}_{\mathrm{j}}^{\max }$ of $\mathrm{j}$-th limitation.

The generalized quality criterion is determined as a cross of all vague criteria and limitations, presented by their membership functions. This problem is reduced to the standard problem of nonlinear programming: to find such values of $X$ and $\lambda$, that:

$$
\begin{aligned}
& \lambda=\mu_{\mathrm{Ki}}(X), \quad j=1,2, \ldots, \mathrm{n}, \\
& \lambda=\mu_{\mathrm{cj}}(X), \quad j=1,2, \ldots, \mathrm{q} .
\end{aligned}
$$

The complex estimation of the quality of products included and generalized all parameters of the studied samples. The additive model was expressed as average weighted arithmetic values [17].

The main advantage of the presented model is in reflection of the internal interconnection of unit and complex parameters:

$$
\mathrm{K}_{\mathrm{o}}=\sum_{\mathrm{i}=1}^{\mathrm{n}} \mathrm{M}_{\mathrm{i}} \cdot \mathrm{K}_{\mathrm{i}} \text {, }
$$

where $\mathrm{K}_{0}$ - generalized quality parameter; $\mathrm{M}_{\mathrm{i}}$ - ponderability coefficient of $\mathrm{i}$-th quality parameter; $\mathrm{K}_{\mathrm{i}}$ - relative quality parameter.

For obtaining the complex estimation of the quality of fresh-mixes, there were studied the following groups of parameters, which determination was realized in correspondence with existent standards and methods: $\mathrm{P}_{1}$ - organoleptic parameters (SSTU ISO 6658-2016); $\mathrm{P}_{2}$ - physical-chemical parameters (SSTU 7159:2010); $\mathrm{P}_{3}$ - food value parameters (CODEX STAN 247-2005); $\mathrm{P}_{4}$ - biological value parameters; $\mathrm{P}_{5}$ - safety parameter (SSTU 4069:2016).

Coefficients of ponderability of quality parameters were calculated by the data, presented by experts, and corresponded to the requirement, expressed in the formula: 


$$
\sum_{i=1}^{\mathrm{n}} \mathrm{M}_{\mathrm{i}}=1
$$

where $\mathrm{M}_{\mathrm{i}}$ - ponderability coefficient of $\mathrm{i}$-th parameter $\left(\mathrm{M}_{\mathrm{i}}>0\right) ; \mathrm{n}-$ number of products quality parameters.

$$
\mathrm{M}_{\mathrm{i}}=\frac{1}{\mathrm{~N}} \sum_{\mathrm{j}=1}^{\mathrm{N}} \mathrm{M}_{\mathrm{ij}}, \quad \mathrm{i}=1,2,3 \ldots \mathrm{n}
$$

where $\mathrm{M}_{\mathrm{i}}$ - mean arithmetical value of the ponderability coefficient $\mathrm{i}$-th quality parameter; $\mathrm{N}$ - number of experts; $\mathrm{M}_{\mathrm{ij}}$ - ponderability coefficient of $\mathrm{i}$-th parameter, given by $\mathrm{j}$-th expert $(j=1,2,3 \ldots N)$.

Biological activity (BA) of fresh-mixes was determined using [18], the electronic-transport model $-\mathrm{NAD} \cdot \mathrm{H}_{2}-\mathrm{K}_{3}\left[\mathrm{Fe}(\mathrm{CN})_{6}\right]$ presented on Fig. 2.



Fig. 2. Electronic-transport model $\mathrm{NAD} \cdot \mathrm{H}_{2}-\mathrm{K} 3\left[\mathrm{Fe}(\mathrm{CN})_{6}\right]$

This criterion is widely used for the preliminary integral estimation of the quality of both ready products and ingredients, included in the recipe of developed beverages [19].

Any deviations from the physiological control, for example, starvation or diseases, are accompanied by the decrease of NAD / NAD $\cdot \mathrm{H}_{2}$. At that the increase of NAD creates conditions for energetic homeostasis activation [20]. Processes, which mechanism includes oxidation of NAD $\mathrm{H}_{2}$ to NAD prevail in a cell, and this mechanism of transferring electrons from the oxidized substrate to oxygen is the main energy source for the growth and development of a cell [20]. Thus, NAD transformations in $\mathrm{NAD} \cdot \mathrm{H}_{2}$ are essential for cellular redox-properties and regulate intracellular metabolic processes [21].

The ability of different biologically active components of vegetable raw materials to cause non-fermented oxidation of NAD $\mathrm{H}_{2}$ to NAD and synchronously to restore $\mathrm{Fe}^{+3}$ to $\mathrm{Fe}^{+2}$ demonstrates that these substances can raise the general non-specific resistance of the organism [21].

For the control experiment, $3 \mathrm{~cm}^{3}$ of the solution of potassium ferricyanide, $6 \mathrm{~cm}^{3}$ of the buffer solution with $\mathrm{pH}=7$ and $1 \mathrm{~cm}^{3}$ of $\mathrm{NAD} \cdot \mathrm{H}_{2}$ solution were set in a dry test-tube. The mixture was fast intermixed, and its optical density was determined. Distilled water is a solution of comparison.

$\triangle \mathrm{AK}$ value of the control sample was calculated by the formula:

$$
\Delta \mathrm{AK}=\mathrm{AK}_{1}-\mathrm{AK}_{2}
$$

where $\triangle \mathrm{AK}$ - change of optical density of the control system as a result of direct oxidation of NA$\mathrm{D} \cdot \mathrm{H}_{2}$ of potassium ferricyanide, $\mathrm{AK}_{1}$ - initial optical density, $\mathrm{AK}_{2}$ - optical density in $180 \mathrm{~s}$.

The study of the material sample. $3 \mathrm{~cm}^{3}$ of the solution of potassium ferricyanide, $5 \mathrm{~cm}^{3}$ of the buffer solution with $\mathrm{pH}=7$ and $1 \mathrm{~cm}^{3}$ of $\mathrm{NAD} \cdot \mathrm{H}_{2}$ and $1 \mathrm{~cm}^{3}$ of the studied material were set in a dry test-tube. The mixture was fast intermixed, and its optical density was determined. $9 \mathrm{~cm}^{3}$ of distilled water and $1 \mathrm{~cm}^{3}$ of the studied material were a solution of comparison. 
$\triangle \mathrm{AM}$ value of the control sample was calculated by the formula:

$$
\Delta \mathrm{AM}=\mathrm{AM}_{1}-\mathrm{AM}_{2}
$$

where $\triangle \mathrm{AM}$ - change of optical density of the system at the material, $\mathrm{AM}_{1}$ - initial optical density, $\mathrm{AM}_{2}$ - optical density in $180 \mathrm{~s}$.

Biological activity (BA) is calculated by the formula:

$$
\mathrm{BA}=\frac{\Delta \mathrm{AM}}{\Delta \mathrm{AK} \cdot \mathrm{m}_{\text {sample }}} \cdot \mathrm{V}_{\text {sol }}
$$

where $\mathrm{V}_{\text {sol }}$ - solution volume of the studied sample $\mathrm{m}_{\text {sample }}$ - mass of the studied sample.

For prognosticating the real storage term, there was used ASLT test, where the dependence of the process of changes of commodity parameters and safety ones of beverages on storage time and temperature was studied. The main quality parameters were organoleptic and microbiological ones.

The developed beverages were divided in samples with volume $50 \mathrm{~cm}^{3}$, which temperature was changed from $5{ }^{\circ} \mathrm{C}$ to $15^{\circ} \mathrm{C}$ at storage, with the step $5^{\circ} \mathrm{C}$, and storage term - from 12 to 72 hours with the step 12 hours [22].

The produced beverages were divided in samples of $50 \mathrm{~cm}^{3}$, stored at the temperature from $5{ }^{\circ} \mathrm{C}$ to $15^{\circ} \mathrm{C}$, with the step $5{ }^{\circ} \mathrm{C}$, and storage term from 12 to 72 hours with the step 12 hours [22].

\section{Conclusions}

1. There was realized mathematical optimization of the component composition of fresh-mixes "Potassium-mix" and "Potassium-mix plus". Fresh-juices: pomegranate, beet, pumpkin, apple and grapefruit were used as vegetable raw materials. Turmeric in $1 \%$ concentration was used as a spicy-aromatic raw material. Glutin was a protein additive. Its $2 \%$ concentration in a beverage supplies the human organism with enough amounts of oxylizin and oxyproline.

2. The data, received at ALST-test at storage, demonstrated that sensory parameters of beverages don't change during 5 days at the temperature $(5 \pm 1){ }^{\circ} \mathrm{C}$ in a hermetic package. The growth of biomass of pathogenic and conventionally pathogenic microorganisms is not also observed at such storage conditions.

3. The elaborated comprehensive approach to developing beverages with the cardioprotective effect can be used in practice for producing different functional products. The advantages of this study are the development of recipes of beverages with the balanced potassium-protein composition. The obtained beverages can be recommended for child, gerodietical and cardio-food. They can be included in food rations of health-improving institutions and also be realized by retail trade. For introducing in production, it is planned to realize SWOT-analysis of obtained products and also to obtain the complex commodity parameter. In further works it is planned to determine the complex parameter of the quality of fresh-juices and calculation of the competitiveness parameter.

\section{References}

[1] Cherevach, E. Y., Tenkovskaya, L. A. (2015). Razrabotka tekhnolohy funktsyonalnikh napytkov na molonoi sivrotke s rastytelnimy ekstrektamy. Food Processing: Techniques and Technology, 39 (4), 99-105.

[2] Arseneva, T. P., Borzdaia, E. V., Stryzhneva, O. N. (2015). Razrabotka pyvopodobnoho napytka na osnove permeata molochnoi sivorotky. Nauchnii zhurnal NYU YTMO. Seryia «Protsessi y apparati pyshchevikh proyzvodstv», 3, 136-141.

[3] Pavliuk, R. Yu., Poharskaia, V. V., Abramova, T. S., Berestovaia, A. A., Loseva, S. M. (2014). Development of functional health nanodrinks based on milk whey. Eastern-European Journal of Enterprise Technologies, 6 (10 (72)), 59-64. doi:10.15587/1729-4061.2014.31592 
[4] Ustenko, I. A. (2015). Application of swot analysis in the development and promotion of enriched drinks. Eastern-European Journal of Enterprise Technologies, 2 (10 (74)), 25-31. doi: 10.15587/17294061.2015.39762

[5] Prykhodko, Yu. V., Palahyna, M. V., Cherkasova, S. A. (2007). Razrabotka tekhnologii kislomolochnykh funktsional'nykh napitkov, obogashchennykh rybnym belkovym kontsentratom. Izvestyia vuzov. Pyshchevaia tekhnolohyia, 3, 73-75.

[6] Averianova, N. D., Tsymbyzova, M. E. (2008). Byoprodukti na osnove hidrobiontov i ikh funktsionalnaia znachimost. Vesnyk AHTU, 3 (44), 115-119.

[7] Kushnir, N. A. (2015). Vyznachennia zbalansovanosti aminokyslotnoho skladu kolahenovoho preparatu. Prohresyvni tekhnika ta tekhnolohii kharchovykh vyrobnytstv restorannoho hospodarstva i torhivli, 1 (21), 458-468.

[8] Dzyuba, N., Bilenka, I., Palvashova, A., Zemlyakova, E. (2017). Study into collagen hydrolyzate applicability as a structure forming agent. Eastern-European Journal of Enterprise Technologies, 5 (11 (89)), 10-17. doi: 10.15587/1729-4061.2017.110498

[9] Serdechno-sosudistye zabolevaniya (2015). Informatsyonnii biuleten VOZ, No. 317. Available at: http://www.who.int/mediacentre/factsheets/fs317/ru/

[10] Golubtsova, Y. V. (2017). Physical and chemical indicators and merchandasing assessment of wild strawberry, gooseberry, cherry, raspberry, banana, wild rose and kiwi. Foods and Raw Materials, 5 (1), 154-164. doi: 10.21179/2308-4057-2017-1-154-164

[11] Ivanov, S. V., Hrek, E. V., Krasulia, E. A. (2014). Modelyrovanye v tekhnolohy sivorotochnikh napytkov s povishennoi viazkovstiu. Tekhnika i tekhnolohyia pyshchevikh proyzvodstv, 3, 39-46.

[12] Grek, E. B., Krasulya, E. A. (2015). The behavior prediction of raw material systems in the technology of whey beverages. Foods and Raw Materials, 3 (1), 21-26. doi: 10.12737/11233

[13] Dzyuba, N. A., Valevskaya, L. A. (2017). Kompleksnaya otsenka kachestva kyslorodnoho kokteilya «Hlotok zdorovya». The scientific heritage, 9 (9), 1, 96-107.

[14] Telezhenko, L. M., Dzyuba, N. A., Kashkano, M. A., Valevskaya, L. O. (2016). Osnovy naukovykh doslidzhen. Kherson: Hrin D.S., 192.

[15] Telezhenko, L. N., Kashkano, M. A. (2014). Kompleksnaya otsenka kachestva polykomponentnikh krupianikh zapekanok. Izvestyia visshykh uchebnikh zavedenyi. Pyshchevaia tekhnolohyia, 1 (337), 101-104.

[16] Dzyuba, N. A., Valevskaya, L. A. (2017). Comprehensive quality assessment composition functional flour products. European Journal of Technical and Natural Sciences, 3, 32-40. doi: 10.20534/ ejtns-17-3-32-40

[17] Khomych, H. P., Vikul, S. I., Kapreliants, L. V., Osypova, L. A., Lozovska, T. S. (2015). Pat. No. 107506 UA. Sposib vyznachennia biolohichnoi aktyvnosti obiektiv pryrodnoho pokhodzhennia. MPK G 01N 33/00 (2015.01). No. a201302626; declareted: 04.03.2013; published: 12.01.2015, Bul. No. 1.

[18] Vykul, S. I. (2012). Byolohycheskaya aktyvnost rastytelnoho siria- inhredyenta pyshchevikh produktov. Kharchova nauka i tekhnolohiia, 4 (21), 40-44.

[19] Panyn, L. E. (1983) Byokhymycheskye mekhanyzmi stressa. Novosibirsk: Nauka, 216.

[20] Khalmuratov, A. H., Totskyi, V. N., Chahovets, R. V. (1982). Membrannii transport kofermentnikh vytamynov i kofermentov. Kyiv: Naukova dumka, 280.

[21] Dzyuba, N. A., Oliiynik, M. I., Bezzodina, A. R. (2017). ASLT-Test - Methods for determining shelf-life of high-protein desserts. Science and society. Hamilton: Accent Graphics Communications and Publishing, 15-20. 